Sharif University of Technology
Scientia Iranica
SCIENTIA
I RAN I C A

\title{
Resilient approach toward urban development in lake catchments; case of Lake Urmia
}

\author{
A. Ahmadi ${ }^{a, *}$, M. Abbaspour ${ }^{b}$, R. Arjmandi ${ }^{a}$ and Z. Abedi ${ }^{a}$ \\ a. Department of Environmental Management, Science and Research Branch, Islamic Azad University, Tehran, Iran. \\ b. School of Mechanical Engineering, Sharif University of Technology, Tehran, Iran. \\ Received 21 January 2015; received in revised form 17 May 2015; accepted 16 June 2015
}

\author{
KEYWORDS \\ Lake Urmia; \\ Drying out; \\ Urban development; \\ Resilient city; \\ Wetland HSE Index \\ (WHSEI).
}

\begin{abstract}
The climate change and human development in lake catchments have put these habitats in drying conditions, e.g. Aral Sea in Asia, Lake Chad in Africa, Lake Mead in USA, Lake Urmia in Iran, etc. These ecosystems play an important role in social, ecological, and economic activities. Lake Urmia, recognized as an international wetland in 1973 and located in Iran, which is the second largest hypersaline lake in the world, is in the same state. Lake Urmia biologically and ecologically is one of the most interesting places in the world. This lake is a habitat for various species. The lake's surface has shrunken from $6000 \mathrm{~km}^{2}$ to $900 \mathrm{~km}^{2}$ in 2013 . The statistics indicate that the population has increased by $13 \%$ during this period, which shows that in addition to natural causes such as climate change and global warming, human related issues like population growth and urban development have the most important role in the lake's status. This paper presents an innovative method for estimating the wetland HSE statues to make preventive measures and bring an acceptable coexistence of both the lake with all its ecological and environmental features and the urban areas as sustainable and resilient cities.

(C) 2016 Sharif University of Technology. All rights reserved.
\end{abstract}

\section{Introduction}

The climate change and human development in lake catchments have put these habitats in drying conditions, e.g. Aral Sea in Asia, Lake Chad in Africa, Lake Mead in USA, Lake Urmia, etc. These ecosystems play an important role in social, ecological, and economical activities; also, they greatly contribute to human and wildlife well-being by climate regulation, water supply, water purification, providing nutrition, etc.

Aral sea, previously the fourth largest lake in the world, which lay between Kazakhstan in the north and Uzbekistan in the south, is one of human intervention

*. Corresponding author.

E-mail addresses: ahmadyaida@yahoo.com (A. Ahmadi); abbpor@sharif.edu (M. Abbaspour);

rezaarjmandi@gmail.com ( $R$. Arjmandi);

abedi2015@yahoo.com (Z.Abedi) in to natural ecosystems [1]. The policy of Soviet Union to increase the cotton products by implementing considering irrigation projects, in 1950s was resulted in drying of Aral Sea [2]. It led to decrease of $23 \mathrm{~m}$ in lake level, $90 \%$ in volume, and grow of salinity from $10 \mathrm{~g} / \mathrm{l}$ to more than $100 \mathrm{~g} / \mathrm{l}$; overall, it caused negative changes in human health, ecology, economy, and society [3].

Lake Chad is a vital source of water near Sahara Desert, which is the largest freshwater lake of Africa and holds a large area of wetlands with significant size and ecological values [4]. Droughts have vanished $90 \%$ of the lake throughout three decades, which have caused decreased groundwater level, disappearance of specific plant species, loss of wildlife populations, increased soil erosion and loss of fertility, reduction in rainfed, irrigated crops, etc. [5].

Lake Mead, the largest reservoir in the United States, is a national recreation area with substantial biodiversity. Human development activities have 
caused considerable diverse impacts on the regional economy and wildlife [6].

An extensive literature review was carried out in order to find out any kind of indices which could indicate the status of well-being of a wetland. Spenser et al. presented a rapid appraisal wetland condition index in south-eastern Australia in 1998 [7]. This index was composed of thirteen indicators related to wetland function, but it needed a long-term monitoring data set and also a mixture of visual estimates and measurements to define these indices. Even though this method presented some valuable results, it could not cover the risk and social aspects. Jiang et al. presented another index, so-called EBLE, which stands for a multi-scale evaluation index system including environmental quality, biology and ecology, landscape pattern, and ecosystem management [8]. However, this method was not also able to cover all different aspects of well-being of a wetland and nearby areas.

Wetland shrinkage or disappearance has a growing trend all over the world, including Lake Urmia in the north western of Iran. The above shortcomings were the motivation behind the definition of a new index, i.e. Wetland HSE Index (WHSEI). Since this index can cover all different aspects of wetland functions, including health issues, environmental conditions, and social and economic aspects, it can be globally implemented for any wetland.

\section{Case of Urmia}

Lake Urmia is the second largest hypersaline lake in the world which has active food chain. It supports green and blue-green algae that nourish endemic brine shrimp Artemia urmiana that has an important part in feed- ing Pelecanus onocrotalus, Egretta garzetta, Plegadis falcinellus, Platalea leucorodia, Phoenicopterus ruber, Tadorna ferruginea, Tadorna tadorna, Himantopus himantopus, Recurvirostra avosetta, Tringa tetanus, Larus cachinnans armenicus, Larus genei, etc. [9-11].

There are around 102 rocky Islands in the lake which create a winter habitat for migrating water birds to feed and breed. They are also home to endangered mammals such as Dama mesopotamica and Ovis orientalis gmelini. The lake is also valuable in terms of tourism and therapeutic benefit because of its salinity. Lake Urmia as an important natural asset, with considerable cultural, economic, aesthetic, recreational, scientific, conservation, and ecological values, has been declared as a Wetland of International Importance in Ramsar Convention, and in 1976, UNESCO announced it as a Biosphere Reserve [11-13].

Human activities and climate change have caused divers effects on most parameters of prime geographical and climate specification of Lake Urmia (Tables 1 and 2) $[14,15]$.

The features of wetlands contribute to human welfare and make them vital ecosystems not only for wildlife but also for mankind; in case of Urmia, it provides salt production, food for animals, Artemia harvesting, control over ground water salinity, waterbirds, therapeutically used herbs, hunting, tourism, recreation, etc.

Urmia basin is surrounded with mountains, foothills, and savannas which are divided between three provinces: $51 \%$ West Azerbaijan, 39\% East Azerbaijan, and $10 \%$ Kurdistan $[11,16,17]$.

There are more than 55 cities and 3026 villages in Urmia catchment with around 6 million people, most of whom are farmers and ranchers [14,17].

Table 1. Prime geographical specifications of Lake Urmia.

\begin{tabular}{ll}
\hline \multicolumn{1}{c}{ Title } & \multicolumn{1}{c}{ Description } \\
\hline Geographical coordinates & $37^{\circ} 06^{\prime} 15^{\prime \prime}$ and $38^{\circ} 15^{\prime} 15^{\prime \prime}$ North and $45^{\circ} 00^{\prime} 13^{\prime \prime}$ and $45^{\circ} 55^{\prime} 20^{\prime \prime}$ East \\
Area & $5000-6000 \mathrm{~km}^{2}$ \\
Length & $130-146 \mathrm{~km}$ \\
Width & $15-58 \mathrm{~km}$ \\
Altitude & $1276 \mathrm{~m}$. amsl \\
The average water volume & 32 million cubic meters \\
North basin & Aras river \\
South basin & Sefid rod and Sirvan rivers \\
West basin & Zab river \\
East basin & Sefid rod river \\
& Zarineh rod, Simineh rod, Godar chai, Aji chai, Barandazo chai, Nazlou \\
Rivers leading into the lake & chai, Shahr chai, Zola chai, Sofi chai, Azar shahr, leilan chai, Mardogh chai, \\
& Ghale chai, Mahabad chai, etc. \\
Most important islands & Kabodan national park, Ashk, Azro, and Espiro \\
\hline
\end{tabular}


Table 2. Prime climate specifications.

\begin{tabular}{ll}
\hline \multicolumn{1}{c}{ Title } & \multicolumn{1}{c}{ Description } \\
\hline Basin precipitation & Mediterranean and some like-Mediterranean areas \\
Average rainfall & $317 \mathrm{~mm}$ \\
Average annual temperature & From 11 to $13{ }^{\circ} \mathrm{C}$ \\
Average humidity during the cold months & $63 \%$ \\
Climate & Semi-humid, with cold winters and mild summers and semi-arid \\
& central area \\
\hline
\end{tabular}

More than 76 dams on rivers leading to the lake are collecting about 2068 million cubic meters per year of water from the catchment for supplying water, of which $88.9 \%$ is used for agricultural purposes [17].

The surface of Lake Urmia has been significantly reduced and its depth has fallen by almost 7 meters compared to previous years; also, the water volume has decreased from 42 milliard cubic meters in 1995 to 22 milliard cubic meters in 2010 [10,18-20].

The present state of Lake Urmia is the result of global climate change, evaporation, development of non-mechanized agriculture in the Lake Catchment, surface flow diversions, groundwater extraction, lack of efficient water management, dams in the watershed and also Shahid Kalantary causeway which crosses the lake, etc.

Lake Urmia holds an estimated 8 million cubic metric tons of salt [11]. Input efficiency caused an increase in the amount of salt in its 40 years average, which resulted in huge salt deposits.

If the lake dryout occurs, a vast amount of salt in form of particular matter will be released into the region atmosphere, resulting in an ecological, agricultural, and social catastrophe. It will force many people to abandon their villages and towns around the lake and immense majority of the flora and fauna will be lost permanently [13].

These changes jeopardized Lake Urmia life, which designates that even though urban development has aimed toward welfare of citizens, in long-term, the consequences of these actions could result in unpredictable negative impacts.

\subsection{Aftermath of Lake Urmia dry-out}

- Desertification in National Park of Lake Urmia;

- Threatened farmlands around the lake;

- Loss of income security for the catchment population;

- Threatened wildlife of Urmia Islands;

- Loss of valuable and rare source of Artemia in Urmia;

- Decline in the number of local and migratory birds branches;
- Jeopardized tourism economy in the area of Urmia;

- Disappearance of the lake's therapeutic values;

- Presence of huge amount of salt on the dried lake bed;

- The potential of salt particular matter spreading all over the region;

- Decline in biological value of the lake;

- Remaining saline water of the Lake, which changes into super saturated saline water [21].

The critical condition of Lake Urmia and some other wetlands in the world was an inspiration to introduce innovative methods for estimating the wetland HSE status to make preventive measures to increase resiliency and sustainability of the cities in the vicinity of wetland catchments.

\section{Wetland HSE Index (WHSEI)}

The health, safety \& loss, and environmental issues are major concerns for well-being of wetlands. This paper introduces some factors to provide certain enabling tools for experts to monitor the situation of wetlands. The quantitative measures of these factors will provide decision makers with enough information to follow the development progress in a resilient manner.

These factors can be divided in three categories that are health, safety \& loss, and environment, which their changes can be monitored regularly (e.g., annually).

\section{Health factors:}

1. Changes in the number of people visiting the lake for treatment and water therapy (\%) $I_{w t}$;

2. Changes in the number of patients admitted to medical centers for respiratory diseases associated with changes in wetland status $(\%) I_{r d}$;

3. Changes in the number of patients admitted to the medical centers for skin diseases related to changes in wetland status $(\%) I_{s d}$;

4. Changes in the number of patients admitted to the medical centers for eye diseases associated with changes in wetland status (\%) $I_{e d}$; 
5. Changes in the number of patients admitted to medical centers with diseases related to heavy metals in consumed salt (\%) $I_{h m}$;

6. Changes in the number of patients admitted to medical centers for thyroid gland diseases $(\%) I_{e d}$.

\section{Safety and loss factors:}

1. Changes in recreation activities revenue (\%) $I_{\text {inc }}$;

2. Changes in the cost of producing agricultural yields (\%) $I_{\text {agr }}$;

3. Changes in tonnage of agriculture products (\%) $I_{t p}$;

4. Changes in the related health care costs, such as respiratory and skin problems (\%) $I_{m e}$;

5. Changes in immigration rate as a result of changes in wetland status (\%) $I_{i e}$.

\section{Environmental factors:}

1. Changes in regional climate due to humidity levels variations of the wetland (\%), $I_{h}$;

2. Changes in regional climate due to precipitation variations (\%), Ip;

3. Changes in regional climate due to temperature changes in wetland catchment (\%), $I_{t}$;

4. Changes in biodiversity (wildlife, birds, fish, vegetation, population, etc.) (\%), $I_{\text {bio }}$;

5. Changes in physical status of the wetlands (\%), $I_{\text {TDS }}$; TDS: Total Dissolved Solid;

6. Changes in chemical status of the wetlands (\%) $I_{\mathrm{DO}} ;$ DO: Dissolved Oxygen;

7. Changes in wetland water $\mathrm{pH}(\%), I_{p H}$;

8. Changes in the temperature of wetland water (\%), $I_{w t}$;

9. Changes in groundwater quality of the catchment (according to local standards) (\%), $I_{w q}$;

10. Changes in area of land under cultivation $(\%), I_{l c}$;

11. Changes in soil quality of the catchment $(\%), I_{s q}$;

12. Changes in air Quality Risk Index (\%), $I_{\mathrm{AQRI}}$ [22].

To evaluate Wetland HSE Index (WHSEI), the following steps should be taken:

I. Identification of existing status for all defined factors of the wetland;

II. Setting an auditing program in order to monitor changes of the selected factors on annual basis;

III. Executing necessary actions to keep these factors within a satisfactory range.

\subsection{Calculation of WHSEI}

Result of each factor according to expert's opinions and the regional standards definition will be scored within the range of: acceptable, 10 (green); moderate, 5 (yellow); and critical, 0 (red), as it is shown in Table 3.

According to Eq. (1), total scores should be recorded. The sum of total scores should be divided to the number of measured parameters, NF, and the results should be multiplied by 10 (Eq. (2)) to obtain Wetland Health, Safety \& loss, and Environment Index (WHSEI):

$$
\begin{aligned}
& N_{F}=10 N F_{A}+5 N F_{M}+0 N F_{C} \\
& \sum F_{S}=N F_{A}+N F_{M}+N F_{C} \\
& \text { WHSEI }=\frac{\sum F_{s}}{N_{F}} \times 10 .
\end{aligned}
$$

where:

$N F_{A} \quad$ Number of acceptable factors

$N F_{M} \quad$ Number of moderate factors

$N F_{C} \quad$ Number of critical factors

$\sum F_{S} \quad$ The sum of factor scores

$N_{F} \quad$ Number of factors

According to results of WHSEI, the statues of the wetland (Table 4) can be estimated.

\section{Results and recommendations}

Resiliency for cities in the vicinity of catchment areas will not be achieved if bilateral effects of human development and lakes or well-being of wetlands are

Table 3. WHSEI evaluation table.

\begin{tabular}{ccccc}
\hline Code & Factors & $\begin{array}{c}\text { Acceptable } \\
\text { (10) }\end{array}$ & $\begin{array}{c}\text { Moderate } \\
\text { (5) }\end{array}$ & $\begin{array}{c}\text { Critical } \\
\text { (0) }\end{array}$ \\
\hline 1 & $I_{w t}$ & & & \\
2 & $I_{r d}$ & & & \\
3 & $I_{s d}$ & & & \\
$\vdots$ & $\vdots$ & & & \\
21 & $I_{l c}$ & & & \\
22 & $I_{s q}$ & & & \\
23 & $I_{\mathrm{AQRI}}$ & & & \\
\hline Sum of factors & $N_{A}$ & $N_{M}$ & $N_{C}$ \\
\hline
\end{tabular}

Table 4. Index evaluation.

\begin{tabular}{lc}
\hline \multicolumn{1}{c}{ Score } & WHSEI \\
\hline Acceptable (A) & 75 to 100 \\
Moderate (M) & 40 to $<75$ \\
Critical (C) & 0 to $<40$ \\
\hline
\end{tabular}


not taken seriously; WHSEI can be used to make these activities to be in accordance with sustainable and resilient concepts.

Implementation of Wetland HSE Index can assist decision makers and authorities in several ways including:

- The general status of wetland will be determined;

- Factors threatening the wetland will be identified by degree of importance;

- With the knowledge of WHSEI status, there will be comprehensive information on wetland catchment which can be used for EIA (Environmental Impact Assessment) and other related activities for executing any development projects;

- WHSEI can be used as a tool to find the status of each factor within three categories of A, M, and C, which as a result will encourage the decision makers to take the improving steps;

- WHSEI can help to introduce new means for development plan on the catchment area with the least diverse effects on the health and environment;

- Implementing WHSEI and other indices like Air Quality Risk Index can be a tool for comparative survey of cities' resiliency at national or international levels;

- WHSEI can be implemented for any lake or wetland around the world, which will enable the authorities to audit the well-being of these water bodies.

\section{References}

1. Micklin, P. "The aral sea disaster", Annual Review of Earth and Planetary Sciences, pp. 47-72 (2007).

2. Whish-Wilson, P. "The Aral sea environmental health crisis", Journal of Rural and Remote Environmental Health, I(2), pp. 29-34 (2002).

3. Jensena, S., Mazhitovab, Z. and Zetterströmc, R. "Environmental pollution and child health in the Aral sea region in Kazakhstan", Science of The Total Environment, 206, pp. 187-193 (1997).

4. Oddad, E., Oyebande, L. and Oguntola, J. "Lake Chad: Experience and lessons learned brief" (2006). Online Available at: http://iwlearn.net/iw-projects/1665/experiencenotes-and-lessons-learned/lakechad_2005.pdf/view (2006) [Accessed 2014].

5. Musa, E. "Saving Lake Chad", in International Commission on Irrigation and Drainage (ICID), Libya (2008).

6. Dickinson, W. "Lake mead national recreation area", (2010). Available at: http://crc.nv.gov/docs/iolll_0410/William [Accessed 2014].
7. Spencer, C., Robertson, A. and Curtis, A. "Development and testing of a rapid appraisal wetland condition index in south-eastern Australia", Environmental Management, 54, pp. 143-159 (1998).

8. Jiang, M., Chen, H., Chen, Q., Wu, H. and Chen, P. "Wetland ecosystem integrity and its variation in an estuary using the EBLE index", Ecological Indicators, 48, pp. 252-262 (2014).

9. Asem, A., Mohebbi, F. and Ahmadi, R. "Drought in Urmia Lake, the largest natural habitat of brine shrimp Artemia", World Aquaculture, 43(1), pp. 36-38 (2012).

10. Asem, A., Rastegar-Pouyani, N., De Los Rios, P., Manaffar, R. and Mohebbi, F. "Biometrical comparison of Artemia urmiana Günther", International Journal of Biological and Life Sciences, 6(2), pp. 100106 (2010).

11. Eimanifar, A. and Mohebbi, F. "Urmia Lake (northwest Iran): A brief review", Saline Systems, 3(5) (2007). Doi: 10.1186/1746-1448-3-5

12. Faramarzi, N. "Agricultural water use in lake Urmia basin, Iran: An approach to adaptive policies and transition to sustainable irrigation water use", Master's Thesis Uppsala University, Department of Earth Sciences (2012).

13. Pengra, B. "The drying of Iran's lake Urmia and its environmental consequences", (2012). Available: http://na.unep.net/geas/ getUNEPPageWithArticleIDScript.php?article_id=79 [Accessed 2014].

14. Environment, D.O., Integrated Management Plan for Lake Urmia Basin, Department of Environment, UNDP, GEF, Conservation of Iranian Wetlands Project, Iran (2010).

15. Noury, M., Sedghi, H., Babazedeh, H. and Fahmi, H. "Urmia lake water level fluctuation hydro informatics modeling using support vector machine and conjunction of wavelet and neural network", Water Resources, 41(3), pp. 261-269 (2014).

16. Karimi, M. "Ecosystem approach as a main strategy for Urmia Lake rescue", in 1st International Conference for Urmia Lake Rescue, Berlin, Germany (2013).

17. United Nations Environment Programme, Sources and Uses of Water in the Basin of Lake Urmia Report, Urmia Lake restoration program, Tehran, Iran, 2014. Available at: http://na.unep.net/geas/ getuneppagewitharticleidscript.php?article_id $=79$

18. Delju, A., Ceylan, A. and Piguet, E. "Observed climate variability and change in Urmia Lake basin, Iran", Theor. Appl. Climatol., 111, pp. 285-296 (2013).

19. Kakahaji, H., Dehghan Banadaki, H., Kakahaji, A. and Kakahaji, A. "Prediction of Urmia lake waterlevel fluctuations by using analytical, linear statistic and intelligent methods", Water Resour Manage, 27, pp. 4469-4492 (2013).

20. Heidari, N., Roudgar, M. and Ebrahimpour, N. "Thermodynamic quantities and Urmia sea water evaporation", Saline Systems, pp. 2-6 (2010). 
21. Hassanzadeh, E., Zarghami, M. and Hassanzadeh, Y. "Determining the main factors in declining the Urmia Lake level by using system dynamics modeling", Water Resour Manage, 26, pp. 129-145 (2012).

22. Ahmadi, A., Abbaspour, M., Arjmandi, R. and Abedi, Z., Air quality risk index (AQRI) and its application for a megacity, International Journal of Environmental Science and Technology, 12, pp. 3773-3780 (2015). DOI 10.1007/s13762-015-0837-7

\section{Biographies}

Aida Ahmadi is an expert in the field of HSE. She is a faculty member at Islamic Azad University, Science and Research Branch (SRBIAU), and has been working with the Center of Environmental and Energy Research \& Studies (CEERS) for the last 10 years. She is also an active member of Iranian Society of Environmentalists. She has participated in different projects related to her field of expertise. The topics of her research interests are in the related fields of environment, health, safety, risk management and HSE, renewable energy, green productivity, and environmental impact assessments and auditing.

Madjid Abbaspour is a full professor and the Head of Marine Group in the School of Mechanical Engineering at Sharif University of Technology (SUT) in Iran. He is also heading the Center for Environment and Energy Research and Studies (CEERS) and the Graduate School of Environment and Energy at Science and
Research Branch of Islamic Azad University (IAU). Furthermore, he is serving as scientific adviser to the Head of High Expediency Council of Islamic Republic of Iran. His research interests are marine industries, ocean engineering, renewable energy, energy engineering, and environmental engineering.

Reza Arjmandi is an Associate Professor and a faculty member in the Department of Environmental Management, Graduate School of the Environment and Energy, Science and Research Branch, IAU, Tehran, Iran. His research interests are environmental economy, sustainable development, environmental management, urban management and environment, and pesticides impacts on the environment.

Zahra Abedi is an Assistant Professor and a faculty member in the Department of Environmental Economics, Graduate School of Environment and Energy, Science and Research Branch, IAU, Tehran, Iran, and Head of Environmental Economic Department of Leadership in National Iranian Productivity Organization (NIPO). Her research interests are green accounting, sustainable development, energy planning and modeling, evaluation of natural and environmental resources, appropriate technology, green productivity techniques, Material Flow Cost Accounting (MFCA) and ISO14051, productivity and competitiveness of industrial sector, management of knowledge and innovation, SMEs networks, risk management, and HSE. 